\title{
TEMPERATURE CHANGES INDUCED BY CONTINUOUS ULTRASOUND*
}

\author{
B. L. MACDONALD, B.Sc. (Physiotherapy), Witwatersrand \\ and
}

S. B. SHIPSTER, B.Sc. (Physiotherapy), Witwatersrand

\section{SUMMARY}

An investigation was undertaken to measure temperature changes during therapeutic ultrasound. Various frequencies, intensities and times were used. As a result of their work the authors feel that more research should be carried out to determine the point at which high intensities of ultrasound produce dangerous temperature increases.

\section{NTRODUCTION}

Controversy exists over the value of ultrasound as a healing modality. We therefore felt that a quantitative evaluation of the temperature changes induced by therapeutic ultrasound was necessary.

According to the Grotthus-Draper law, energy must be absorbed before exposure to it can effect a change. Absorption of ultrasonic energy (orderly movement of particles) results in the conversion of that energy into heat (disorderly movement of particles) (Ter Haar, 1978, Licht, 1958). Absorption by any one tissue depends on that tissue's absorption coefficient and the frequency of the ultrasound. The resultant hyperthermia causes vasodilatation, an increase in blood flow and an increase in metabolic rate. Blood flow increases significantly but decreases rapidly after termination of insonation.

The depth at which heating occurs and therefore the temperature increase in the muscle depends mainly on the intensity of ultrasound applied and the soft tissue cover in the area being treated. It has been found that 5 - 10 minutes of insonation at an intensity of $1 \mathrm{~W} / \mathrm{cm}^{2}$ is necessary to heat the muscle adequately. It is also worth noticing that the hyperthermia which results from an increase in temperature in the muscle is not as great as that occurring in the skin with a comparable increase in temperature.

In our study the temperature changes induced were measured by means of thermocouples inserted into rabbits' legs. The results obtained show some interesting trends.

\section{EXPERIMENTATION}

An anaesthetized rabbit was insonated to evaluate the temperature changes induced by ultrasound. These temperature changes were measured using copper-constantin thermocouples which were inserted into the rabbit's thigh at various levels. The thermocouples were placed in the medial subcutaneous tissue, in the muscle, in the femur and in the lateral subcutaneous tissue. One incision was made on the medial aspect of the thigh to allow for the insertion of the thermocouples. The leg was shaved laterally and medially over the middle third of the thigh. A fine covering of hair was left on the lateral side where the ultrasound was applied.

* This paper is based on a Dissertation submitted in partial fulfilment of the requirements of the degree of B.Sc. (Physiotherapy), University of the Witwatersrand, 1979.

Received 22 December 1980.

\section{OPSOMMING}

Navorsing is gedoen om temperatuurveranderings gedurende toepassing van terapeutiese ultraklank te meet. Verskillende frekwensies, intensiteite en toepassingstye is gebruik. As gevolg van hul resultate voel die skrywers dat meer navorsing gedoen behoort te word om vas te stel waar hoë intensiteite ultraklank gevaarlike temperatuurverhogings produseer.

A Sonacel Multiphon Mark II ultrasound machine was used. This unit is capable of producing a maximum power of 15 watts and has a transducer face with an area of $5 \mathrm{~cm}^{2}$. In this study frequencies of $1,5 \mathrm{MHz}$ and $3 \mathrm{MHz}$ were applied.

In order to prevent the core temperature of the rabbit from dropping a homeothermic blanket control was used. A rectal probe monitored the temperature. The blanket automatically switched on when the temperature dropped and switched off when the temperature had risen to normal.

The ultrasound was applied to the lateral surface of the thigh by/means of a stroking technique. A section approximately $6 \mathrm{~cm}$ long was covered in 10 seconds. At all times the surface of the ultrasound head was held parallel to the thigh. Aquasonic gel was used as a coupling medium. The emf induced in the thermocouples was recorded by a digital voltmeter. These recordings could then be converted to actual temperatures.

Frequencies of $3,0 \mathrm{MHz}$ and $1,5 \mathrm{MHz}$ were applied at intensities of $0,5 \mathrm{~W} / \mathrm{cm}^{2}, 1,5 \mathrm{~W} / \mathrm{cm}^{2}$ and $2,5 \mathrm{~W} / \mathrm{cm}^{2}$ for durations of 3,6 and 9 minutes each. Three readings for each thermocouple were recorded on the digital voltmeter and an average of the three was taken. The ultrasound machine was switched off and the rate of cooling was measured after $30,60,90,120,150,180$, 210,240 and 270 seconds.

Separate control trials were run. The procedure in each case was identical to that described above but with the ultrasound machine switched off.

During experimentation two important observations were made:

- Although the volume of coupling medium was kept constant during the application of ultrasound it spread out to form a thin film between the treatment head and the surface being insonated.

- The rectal temperature remained constant.

\section{DISCUSSION OF THE RESULTS}

The graphical representation of our results showed several interesting features (Figure $1 \mathrm{~A} \& 1 \mathrm{~B}$ ).

The greatest change in temperature $(\triangle T)$ consistently occurred in the lateral subcutaneous tissue. This is accounted for by the fact that the skin had a higher absorption coefficient and was closest to the ultrasound head. It is important to note that the $\Delta \mathbf{T}$ in this region was as high as $14^{\circ} \mathrm{C}$ and in one case the actual temperature was $49,57^{\circ} \mathrm{C}$ (Figure 1A). Clearly had the rabbit not been anaesthetized. severe pain would have been felt since temperatures over $45^{\circ} \mathrm{C}$ damage living tissue. Although blood flow per unit volume is higher in humans than in rabbits, this high increase in tempe- 
INTENSITY

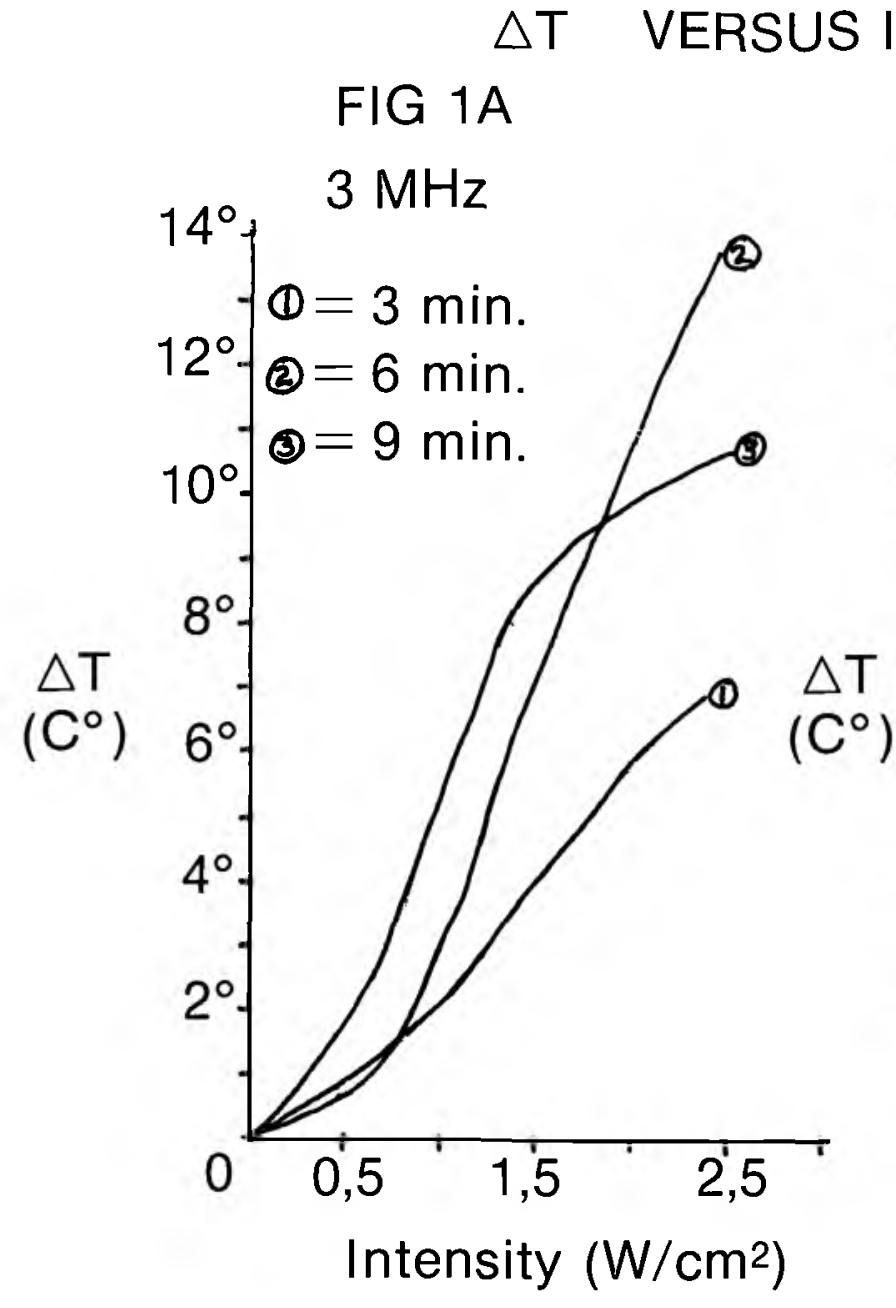

FIG $1 \mathrm{~A}$

$3 \mathrm{MHz}$
FIG 1B

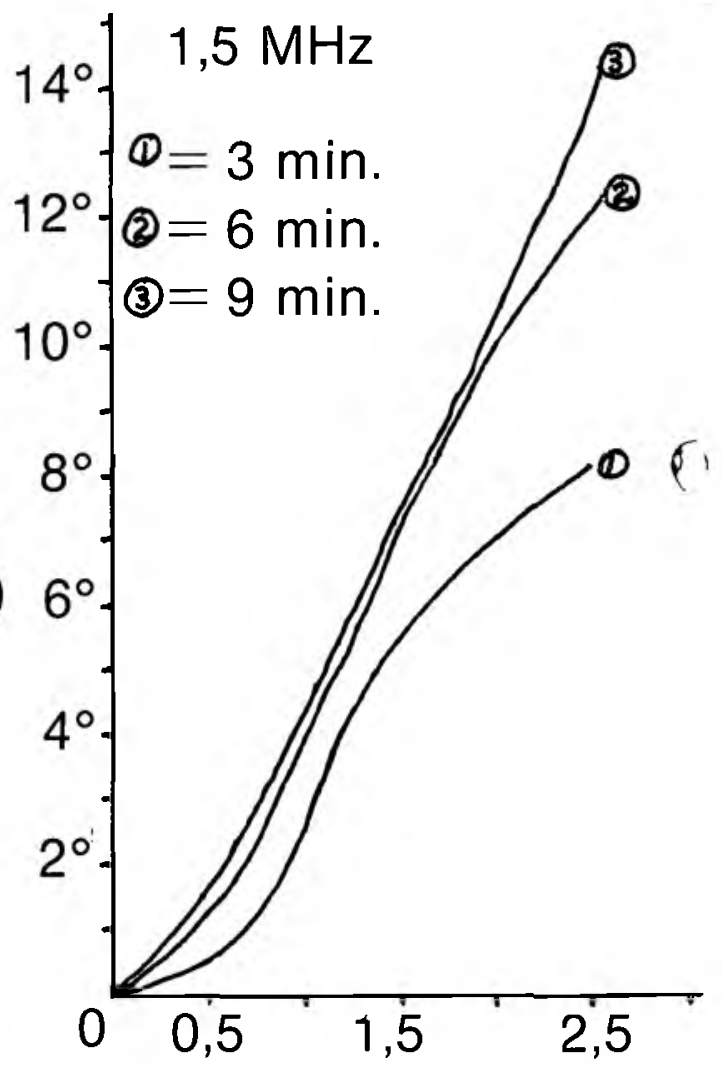

Intensity $\left(\mathrm{W} / \mathrm{cm}^{2}\right)$ rature is important because the possibility of similar increases in temperature in humans cannot be ruled out without further research.

A temperature increase always occurred in the muscle during insonation, and, as in the case of the subcutaneous tissue, $\triangle \mathrm{T}$ increased as intensity and exposure time increased. As was expected, no concentration of heat was found in the muscle because muscle has a low absorption coefficient and a good blood flow.

An interesting phenomenon was the heat concentration which occurred in the bone. This was due to the high absorption coefficient of the bone and its low specific heat. Concentration in the bone would be seen when the energy input was great enough to heat the bone or when blood flow changes did not mask this concentration.

An unexpected rise in $\triangle T$ occurred in the medial subcutaneous tissue. Reflection of the ultrasound probably occurred at the air/tissue interface. This made more energy available for absorption, hence the higher $\triangle \mathrm{T}$.

From the results it was evident that the highest $\triangle \mathrm{T}$ recorded at $3 \mathrm{MHz}$ occurred during the 6 minute applications. In all the thermocouples a drop in $\triangle T$ was produced during the 9 minute applications (Figure 1A and $1 B$ ). The only reasonable explanation for this seems to be that the temperature changes induced after 6 minutes stimulated an increase in blood flow, which then had a cooling effect on the tissues during : longer applications. However, when using $1,5 \mathrm{MHz}$ phenomenon was not noted in any of the thermocouples, i.e. all 9 minute applications produced the greatest $\triangle T$ (Figure $1 \mathrm{~A}$ and $1 \mathrm{~B}$ ).

From this we can infer that blood flow changes occur more rapidly with $3 \mathrm{MHz}$ than $1,5 \mathrm{MHz}$. The shorter the wavelength the greater the energy of the wave and the greater its capacity to interact with matter.

Absorption of ultrasound results in local hyperthermia and when this hyperthermia reaches temperatures of $40-45^{\circ} \mathrm{C}$, hyperaemia results. Temperatures over $45^{\circ} \mathrm{C}$ damage living tissue (Dysan and Suckling, 1978). Although temperature changes alter the local blood flow, these changes are not consistent since they are occurring in a dynamic system. Blood flow changes do, however, seem to depend on the applied intensity of ultrasound and its frequency dependent interaction with tissue.

Absorption of ultrasound in a specific tissue depends on the absorption coefficient. The absorption coefficient increases from fat tissue to muscle to skin and is highest in bone (Hahn, 1978). The behaviour of the heat produced depends on the thermal conductivity $(k)$, thermal capacity (c) and density (p) (Lipkin and Hardy, 1954). However, when dealing with living tissue, heating 
causes vasodilation which modifies the $\mathrm{kpc}$ value for each tissue. Thus the tissue does not display the same heating pattern as would be expected in a similar system, without blood flow.

Temperature increases stimulate an increase in blood flow and this has a cooling effect on the tissue (Stoll, 1960). It was observed that the lateral subcutaneous tissue cooled down most rapidly, followed by the muscle and medial subcutaneous tissue, bone having the lowest cooling rate. In those cases where blood flow changes appear to have been minimal, cooling occurred more rapidly after the $1,5 \mathrm{MHz}$ application than the $3 \mathrm{MHz}$ applications. However, once blood flow changes had been induced, this pattern changed. The cooling rate was variable, probably due to inconsistencies in blood flow changes.

\section{CONCLUSION}

The results of the trials conducted led us to conclude that an increase in temperature can be induced with continuous ultrasound at therapeutic frequencies, intensities and times. The amount of heat produced at different depths changed with intensity and time.
We feel that this study highlights the need for further research to determine the point at which high intensities produce dangerous temperature increases.

\section{References}

Ter Haar, G. (1978). Basic physics of therapeutic ultrasound. Physiother. 64, $100-103$.

Licht, S. (1958). Therapeutic Heat. E. Licht.

Dyson, M. and Suckling, J. (1978). 'Stimulation of tissue repair by ultrasound: A survey of the mechanisms involved'. Physiother. 64, $105-108$.

Hahn, G. M. (1978). Ultrasound for the induction of localized hyperthermia. International Journal of Radiation Oncology, Biology and Physics 4, 1117 . 1118.

Lipkin, M. and Hardy, J. D. (1954). Measurement of some thermal properties of human tissues. Journal of Applied Physiology 7, 212 - 217.

Stoll, A. M. (1960). The role of skin in heat transfer. Transactions of the ASME J. of Heat Transfer 82, $239-242$. 